\title{
Savunma Sanayinin Gelişiminin İhracat-İthalat Dengesi Üzerindeki Etkileri
}

\author{
The Effects of Defence Industry Development \\ on Export-Import Balance
}

Cilt: 16

Say1: 33

\author{
Orkun BAYRAM*
}

\begin{abstract}
$\ddot{O} \boldsymbol{z}$
Ülkemiz, jeopolitik konumu gereği ekonomik ve askerî riskler altında bulunmaktadır. Tarihçemize bakıldığında da savunma sanayine önem verilmesi gereken bir konumda olduğumuz anlaşılmaktadır. Savunma sanayinin gelişimi kavramına bakıldı̆̆ında ise iç ve dış kaynaklardan ihtiyaçların karşılanması ile gelişim sağlandı̆̆ görülmektedir. Savunma sanayindeki gelişmelerin tanımlanmasında literatürde alınan patentler ve istihdam oranı gibi değişkenler temel alınmaktadır. Bu değişkenleri tanımlayan ölçüm değerlerinden biri savunma harcamaları olup harcamaların, savunma ihtiyaçlarının iç veya dış kaynaklardan karşılanması için yapıllyor olması durumuna göre ekonomik büyümeye etkileri farklı olabilmektedir. Bu çalışmada, farklı zamanlarda literatürde yer alan araştırmalar derlenerek savunma sanayinin gelişimi için yapılan harcamaların önemli bir makroekonomik değişken olan ihracat-ithalat dengesi üzerindeki etkileri araştırltmuştır. Farkl dönemlerde yapılan araştırmalarda savunma sanayi için yapılan harcamaların, savunma sanayinde teknolojik düzey arttıkça hem kisa, hem de uzun vadede ihracat-ithalat dengesinde ihracat yönünde olumlu etki yaptı̆̆ gözlenmiştir. Dolayıs ile savunma sanayi yerelleştikçe dış ticaret hacminde ithalatın payı gittikçe düşmektedir.
\end{abstract}

*Dr. Öğretim Üyesi, Antalya Bilim Üniversitesi, Ekonomi Bölümü, ORCID: 0000-0001-9958-7822, e-posta: orkun.bayram@ antalya.edu.tr.

Geliş Tarihi / Submitted : 04.12.2018

Kabul Tarihi / Accepted : 05.02.2020 
164

Güvenlik Stratejileri

Cilt: 16

Sayı: 33

Anahtar Kelimeler: Savunma Sanayi, Savunma Harcamalarl, İhracat-Ithalat Dengesi, Cari Açık, Teknolojik Düzey.

\section{Abstract}

Our country is under economic and military risks due to its geopolitical position. Due to our history, it is understood that we are in a position to give importance to defence industry. When the concept of developments in defence industry is examined, it is seen that development could be provided by meeting the needs from internal or external sources. In defining the developments in the defence industry, variables such as patents and employment rate are taken as basis in the literature. One of the measurement values defining these variables is defence expenditures, and the effects of the expenditures on economic growth may be different depending on whether the defence needs are met by internal or external sources. In this study, the effects of the expenditures made for the development of the defence industry on the export-import balance, which is an important macroeconomic variable, have been investigated. In the researches carried out at different periods, it was observed that the expenditures made for the defence industry had a positive effect on the export-import balance in both short and long term as the technological level in the defence industry increased. Therefore, as the defence industry is localized, the share of imports in foreign trade volume is decreasing.

Keywords: Defence Industry, Defence Spending, Export-Import Balance, Current Account Deficit, Technological Level.

\section{Giriş}

Türkiye, coğrafi konumu ve komşu olduğu ülkeler ve diğer dış güçlerin gütmekte olduğu politikalar sebebiyle ekonomik ve askerî açıdan risk altında bulunan bir ülke konumundadır. Ülkemiz, bu açıdan, sadece bulunduğu kıtada değil, tüm dünya üzerindeki en riskli bölgelerden birinde yer almaktadır. Güney ve güneydoğuda yer alan komşu ülkeler düşünüldüğünde, bu ülkelerin sahip oldukları, başta petrol olmak üzere, çok değerli doğal kaynaklar bulunmaktadır. $\mathrm{Bu}$ kaynaklara hükmetmek isteyen gelişmiş ülkelerin de teşvikleriyle, 
ülkemizin güney ve güneydoğu bölgelerinde, sınır ötesi de dâhil olmak üzere, süreklilik arz eden ekonomik ve din ve mezhep tabanlı çatışmalar meydana gelmektedir. Ülkemizin kuzey ve kuzeydoğu komşuları söz konusu olduğunda ise, bu ülkelerin Sovyet Sosyalist Cumhuriyetler Birliği'nin dağılmasından sonra bağımsız devlet statüsü kazanmış olmaları, hem kendi içlerinde çatışmalara sahip olmalarına, hem de benzer durumdaki komşu bulundukları ülkelerde de aynı sorunların yaşanmakta olmasına neden olmaktadır. Türkiye'nin batısındaki komşuları ile de kita sahanlığı ve münhasır ekonomik bölge gibi konularda uzlaşmazlıkları bulunmaktadır. $\mathrm{Bu}$ sebeplerden dolayı ülkemizin dört bir tarafinda sıcak çatışma ihtimali veya çatışmaların gerçekleşmekte olması söz konusudur. Tüm bunlardan dolayı Türkiye savunma sanayisinin gelişimine dünyada en çok önem vermesi gereken ülkelerden biri konumundadır.

Ülkemizin ve komşu ülkelerin siyasi ve askerî tarihlerine bakıldığında, Türkiye'nin savunma sanayine en çok önem vermesi gereken ülkelerden biri olmasının nedenleri daha net anlaşılabilir. İkinci Dünya Savaşı ile insanoğlunun elde ettiği askerî teknolojiler ve buluşlardan sağlanan faydalar, Soğuk Savaş döneminde de tüm ülkelerin savunma sanayine daha da çok önem vermesine sebep olmuştur. Sovyet Sosyalist Cumhuriyetler Birliği'nin yıkılması ile dünya genelinde daha az bir ivmelenmeye sahip hale gelen savunma sanayileri, Körfez Savaşı, 11 Eylül saldırıları ve sonrasında gelen Afganistan, Irak, Arap Baharı ve Suriye operasyonları tüm ülkelerin savunma odaklı yatırımlarını yeniden arttırmasına neden olmuştur.

Türkiye'nin genel konumuna baktığımızda Kafkasya, Balkanlar ve Orta Doğu coğrafyalarının göbeğinde bulunmasından dolayı ve ayrıca terör örgütleri ve diğer iç çatışma unsurları ile on yıllardır süregelen mücadele içinde bulunması sebebiyle savunma sanayiye sürekli olarak stratejik önem verilmiştir. Ancak savunma ihtiyaçlarının karşılandığı kaynaklar konu edildiğinde, zaman içinde belirli bir istikrar yakalanamamıştır. Ülkemizin kuruluş yıllarından itibaren savunma sanayiye verilen önem gereği, bu sanayinin gelişmesinde belirli aşamalar kaydedilmiştir; ancak Soğuk Savaş döneminde ülkemiz siyasi olarak Amerika Birleşik Devletleri ve aynı bloktaki ülkelere yakın bir tutum 
166

Güvenlik Stratejileri

Cilt: 16

Sayı: 33 ortaya koymuştur. Bu tutumdan dolayı alınan askerî yardımlar ise savunma sanayideki gelişme ivmesini sonlandırmış olup dışa bağımlılık yaratmıştır. Bu dışa bağımlılık, Kıbrıs Barış Harekâtı sonrasında önceden askerî yardım aldığımız ülkelerin bize ambargo uygulaması sebebiyle oldukça olumsuz sonuçlar doğurmuştur. $\mathrm{Bu}$ olaylardan çıkarılan dersler sonrasinda ülkemizde savunma sanayine, yeniden, verilmesi gereken önem verilmeye başlanmıştır. Atıl durumda bulunan savunma sanayi kuruluşları yeniden canlandırılmış olup günümüze kadar olumlu gelişmekte olan bir yükseliş trendi yakalanmıştır.

$\mathrm{Bu}$ yaklaşım çerçevesinde Türkiye'de savunma sanayinin gelişmesinin, süreklilik arz eden ana amaçlardan biri olacağı yorumunda bulunulabilir. Bu durum da savunma sanayini gelişimi için gerekli ekonomik kaynakların tahsisi ile ilgili olası kararları ve bu kararların ülke ekonomisine yapacağı etkileri tartışmayı gerektirmektedir. Savunma ihtiyaçları, pek çok teknoloji ürününü içermekte olup verilmesi gereken en önemli kararlardan biri bu ihtiyaçların ülke içi savunma sanayiden mi, yoksa ülke dışından mı temin edileceği kararıdır. Ülkemizin kuruluş yıllarından Soğuk Savaş dönemine kadar geçen sürede savunma sanayinin gelişimi odaklı yapılan yatırımlarla, bu konuda kendi iç kaynaklarımıza yönelme odaklı bir strateji sergilenmiştir. Çeşitli askerî ve uluslararası birliklere üye olunmasıyla gelen dinamikler neticesinde de bu konuda dışa bağımlı bir strateji kaçınılmaz olmuştur. Ancak Kıbrıs Harekâtı sonrasında dişa bağımlılık politikası terk edilmeye başlanmıştır. Savunma Sanayi Geliştirme Başkanlığı kurulmuş ve savunma sanayi devlet tekelinde olmaktan kaldırılmış, özel kurum ve kuruluşların da savunma sanayinde yer almasına olanak tanınmışırı. ${ }^{1}$

Ülkemiz savunma sanayine özel kurum ve kuruluşların da kazandırılmasıyla savunma sanayine yapılacak yatırımlara daha fazla önem verilmeye başlanmıştır, ancak ülkemiz gelişmekte olan bir ülke

1 Savunma Sanayi ve İmalatçılar Derneği Resmi İnternet Sayfası, "Sektörün Sürdürülebilirliği ve Rekabetçiliğin Geliştirilmesi”, http:/www.sasad.org.tr/uploaded/Sekto run-Surdurulebilirligi-ve-Rekabetciliginin-Gelistirilmesi.pdf(Erişim Tarihi: 10.09.2018) s. 3. 


\section{Savunma Sanayinin Gelişiminin \\ İhracat-İthalat Dengesi Üzerindeki Etkileri}

konumunda bulunduğu için savunma sanayi gelişimi ve yürütülmesi için yapılan harcamalar genel ekonomik durum ve gelişmelerden fazlasıyla etkilenmiştir. 70'li y1llardan 90'lı yıllara kadar savunma sanayi ile ilgili yapılan harcamalarda artışlar meydana gelmiş, ancak 90'l1 y1llardan itibaren yaşanan ekonomik krizler sebebi ile savunma sanayine yapılan yatırım ve harcamalarda düşüş yaşanmıştır. 2005 yılından itibaren ise tekrar bir artış söz konusu olmuştur. ${ }^{2}$

Savunma ihtiyaçlarının iç ve dış kaynaklardan karşılanması şeklinde iki farklı karar türüne bakıldığında, savunma ihtiyaçlarının iç kaynaklardan karşılanması çeşitli ve büyük yatırımlar gerektirdiği görülebilir. Diğer karar türü içinse, bu yatırımlar haricinde, düzenli olarak yapılan harcamaların ülkemizin kendi kuruluşlarına verilen siparişler ile yapılması sağlanabilir; hatta savunma sanayi ürünlerinin diğer ülkelere satılması ile ihracat artışının da sağlanması söz konusudur. Savunma ihtiyaçlarının ülke dışı kaynaklardan karşılanması ise ithalatı arttıracaktır. İki farklı kararın ekonomiye ve özellik ihracat-ithalat dengesine olan etkilerinin incelenmesi farklı durumlarda doğru kararların hangi yönde olduğunun tespiti için gereklidir.

Ülkemizin askerî geçmişi ve diğer ülkelerin tarih boyunca ülkemize karşı sergiledikleri tavırlar gereği savunma ihtiyaçlarının gerektiğinde iç kaynaklardan karşılanabilmesi potansiyelinin yaratılması, bu sebeple de savunma sanayinin gelişimine önem verilmesi gerekliliği doğmuştur. Ancak gelişimin hangi hız ve kapsamda olacağının ve genel gelişme trendinin hangi yönde gerçekleşeceğinin belirlenebilmesi için savunma sanayindeki gelişmelerin, ülkemiz gibi gelişmekte olan ülkelerdeki en önemli ekonomik göstergelerden olan ihracat-ithalat dengesine olan etkilerinin incelenmesi gerekmektedir. Bu çalışma, bu ihtiyaca cevap verme odaklı olup, ülkemizin savunma sanayindeki gelişmelerin ihracat-ithalat dengesine olan etkilerini incelemek ve

\footnotetext{
${ }^{2}$ Şerif Canbay ve Derya Mercan, "Savunma Harcamalarının Ekonomik Büyüme ve Cari İşlemler Dengesine Etkisi: Türkiye Örneği", Journal of Emerging Economies and Policy, 2017, Vol: 2 No:2, 86-104, s. 89.
} 
168

Güvenlik Stratejileri

Cilt: 16

Sayı: 33

tartışmak amaçlanmıştır. Söz konusu edilen iki olgu arasındaki bağlantılar savunma sanayine ilişkin sektör raporları değerlendirilerek ve ayrıca ülkemiz dışında meydana gelen siyasi ve ekonomik gelişmelere dayanarak ortaya konulmaya çalışılmıştır.

Çalışmanın sonraki bölümlerinde öncelikle savunma sanayinin tanımına yer verilecek, daha sonra savunma sanayinde gelişme ile kastedilen faaliyet ve konu başlıkları açıklanacaktır. Literatürde savunma harcamaları savunma sanayi ile ilgili sıklıkla yer verilen bir gösterge olmakla beraber sektördeki kuruluşların, akademiden farklı olarak teknoloji geliştirme ve istihdam gibi göstergeleri de savunma sanayinin gelişimi konu edilirken inceledikleri görülmektedir. $\mathrm{Bu}$ çalışmada, bu tanımların da savunma sanayi açısından önemine yer verilmiştir. Daha sonrasında ise savunma sanayi gelişimi için en çok başvurulan gösterge olan savunma harcamalarının ekonomiye etkileri ile ilgili arz ve talep odaklı görüşler nezdinde bilgi verilecektir. Özellikle de savunma harcamalarının cari açık ve ekonomik büyümeye etkileri, geçmiş araştırmalardan da yola çıkılarak tartışılacaktır. Tüm bunların 1şığında, son yıllarda yıllık olarak sunulan sektör raporları ile savunma sanayinin gelişim trendi, bu trendin yurt dışı satış gelirleri ve ihracat-ithalat dengesi üzerindeki etkileri incelenecektir.

\section{Savunma Sanayi Hizmeti ve Kapsamı}

Savunma sanayi, işlevsel olarak savunma hizmetinin gerçekleştirilebilmesi için gerekli tüm araç, gereç ve hizmetlerin yerine getirilmesini sağlamakla görevli kurum ve kuruluşların oluşturduğu bir bütündür. $\mathrm{Bu}$ sebeple, savunma sanayinin tanımını yapabilmek için savunma hizmetinin içeriğini gözden geçirmek gerekir. Savunma hizmetini, sağlık, konaklama ve yeme içme gibi bireysel kullanıcılar odaklı gerçekleştirilen ve hizmet esnasında her bireyin kişisel faydasının rakamsal olarak ifade edilip ücretlendirilebileceği standart hizmetlerden ayıran belli başlı özellikleri bulunmaktadır. Bu hizmetin en ayırt edici özelliklerinden birisi, diğer hizmetlerin ve tüm faaliyetlerin 
güvenli ve emniyetli bir şekilde gerçekleştirilmesine olanak veren ve onları bütünleyici bir hizmet niteliğinde olmasıdır. ${ }^{3}$ Dolayısıyla, bir ülkede gerçekleştirilen üretim ve hizmet neticelerinde ortaya konulan bilgi ve ürünler ne derece değerli ise, gerekli savunma hizmeti de o derece önem kazanacak ve yoğunluğu artacaktır. ${ }^{4}$ Savunma hizmetinin diğer bir ayırt edici özelliği de, bu hizmetin bütüncül bir hizmet olmasıdır, savunma hizmetinden tüm bireyler aynı anda faydalanabilmektedir, parçalara ayrılması ve bireysel olarak tahsis edilmesi gibi bir durum bulunmamaktadır. ${ }^{5}$

Bir ülkenin savunma hizmetine ihtiyaç duymasının sebepleri olarak sadece ürettiği ürün, bilgi ve hizmetlerin niteliği değil, aynı zamanda o ülkeye özgü çeşitli karakteristiklerin de etkisi söz konusudur. $\mathrm{Bu}$ karakteristiklere örnek olabilecek kavramlar arasında, söz konusu ülkenin jeopolitik konumu, o ülkenin karşı karşıya olduğu iç ve dış tehlikeler ve o ülkenin korumak durumunda olduğu milli çıkarlar gösterilebilir. Savunma hizmetine ihtiyaç duyulmasını sağlayan dinamikler hem savaş hem de barış zamanında var olmaya devam ettikleri için, bu hizmetin de sadece savaş halinde yürütülen bir hizmet olmayıp barış zamanında da yürütülmesi gerekliliği doğmaktadır. Barış halinde ortaya koyulan savunma hizmetleri caydırıcı niteliktedir. Bu nitelikteki savunma hizmetinin başarısı diğer türden savunma hizmetine olan ihtiyacı da düşürecek ve ülkenin refahı açısından çok daha olumlu sonuçlar doğuracaktır. Diğer tür savunma hizmeti de, savaş halinde saldırılara gereken şekilde cevap verilmesi ve ülkenin bütünlügünün korunması için gereklidir. ${ }^{6}$

Savunma hizmetini yürüten devlet kurumu olan ordunun ihtiyaçları arasında olan ürün ve hizmetlerin ortaya koyulması, temin

\footnotetext{
${ }^{3}$ Earl A. Thompson, "Taxation and National Defense", The Journal of Political Economy, 1974, Vol: 82 No:4, 755-782, s. 755.

${ }^{4}$ M. Hanifi Aslan, Hizmet Ekonomisi, Alfa Yayınevi, İstanbul, 1998, s. 19.

${ }^{5}$ Kenan Bulutoğlu, Kamu Ekonomisine Giriș, Demokraside Devletin Ekonomik Kuramı, Yapı Kredi Yayınları, İstanbul, 2003, s. 241.

${ }^{6}$ M. Hanifi Aslan, a.g.y., ss. 249-250.
}

\section{9}

Güvenlik Stratejileri

Cilt: 16

Say1: 33 
170

Güvenlik Stratejileri

Cilt: 16

Sayı: 33 edilmesi, gerçekleştirilmesi sorumluluğunu taşıyan kurum ve kuruluşlar savunma sanayi başlığ altında incelenmektedir. Savunma sanayi ülkedeki tüm iktisadi faaliyetleri ve üretime dayalı yatırımları gerektiğinde koordine etmek durumunda olup, yukarıdaki sorumluluğu taşıyan tüm kamu ve özel sektörde yer alan kurum ve kuruluşları kapsar. Savunma sanayinin diğer sanayi kollarına göre ayırt edici yönlerine bakıldığında ise, ileri teknoloji odaklı olmasının getirdiği farklı özellikler göze çarpmaktadır. İleri teknoloji odaklı tüm sanayi kollarında oldukça yüksek kalite standartları bulunmakta, bu da yeni ürünlerin kullanıma açılma süresini arttırmaktadır. Belli bir ürünü kullanıma açabilmek için gerekli araştırma ve geliştirme faaliyetleri oldukça kapsamlı olup insan hayatına bu derece direkt etki eden ürünlerin geliştirilmesi söz konusu olduğunda hassasiyet derecesi diğer sanayi kollarına göre oldukça yüksek bir düzeye gelmektedir. Savunma hizmeti bireysel olarak sağlanan bir hizmet olmadığ sanayinin ürünleri de tüm topluma hizmet edecek düzeyde ve miktarda üretilmekte, dolayısı ile az sayıda alıcı tarafindan yüksek adette satın almalar söz konusu olmaktadır. Bu durum da müşteri isteklerine tamamen uyum ihtiyacını doğurmakta ve bu sanayi koluna özgü zorlayıcı bir faktör yaratmaktadır. Yine savunma hizmetini ortaya çıkaran nedenlerden birisi ülkenin jeopolitik konumu olduğu için savunma hizmetinin yürütücüsü olan ordunun ihtiyaçlarını karşılayan savunma sanayi de politik koşullardan oldukça etkilenmektedir. ${ }^{7}$

Savunma sanayinin karşılamakla sorumlu olduğu ihtiyaçlara bakıldığında, ülke için söz konusu olan iç ve dış tehditlerle, bulunulan bölge için geçerli olan, komşu devletler ve diğer küresel güçler odaklı askerî kuvvet dengelerine, ayrıca ülkenin üye olduğu uluslararası askerî iş birliği odaklı organizasyonlar veya diğer devletlerle yapılmış olan anlaşmalara bağlı olduğu görülmektedir. Savunma hizmetini sağlayan ordunun ihtiyaçları olarak silah, uçak, tank gibi taşıtların

${ }^{7}$ Özgür Uysal ve Recep Kök, “Ordu Ar-Ge Harcamalarının Ordunun Milli Gelirden Aldığı Paya Oranının Savunma Sanayi Patentlerine Etkileri”, Sanayii Şurası, 2013, Vol: 3, 20-23, s. 23. 
yanında her türlü radar veya cephane gibi tamamlayıcı malzeme ve unsurlara olan ihtiyaçlar da mevcuttur. ${ }^{8}$

Ancak günümüzün ileri teknoloji odaklı savunma sanayi buluşları düşünüldüğünde, ulusal savunma sanayinin bir ülkenin tüm savunma ihtiyaçlarını tek başına karşılaması mümkün olamamaktadır. Savunma ihtiyaçlarının karşılanması için devletlerin alıcı konumunda olmas1 da, bu sebeple söz konusu olup ayrıca farklı farklı ülkelerin ulusal vergi politikaları gereği, yerel savunma sanayi şirketleri yabancı ve büyük ölçekte şirketlerle anlaşmalar yaparak onların tedarik ağının bir parçası olmak durumunda kalmaktadırlar. ${ }^{9}$ Bu şekilde yerel savunma sanayi şirketlerini tedarik ağlarına katan ve gelişen büyük çaplı küresel savunma şirketleri çoğunlukla Amerika Birleşik Devletleri ve Batı Avrupa odaklı bulunmaktadır. ${ }^{10} \mathrm{Bu}$ noktada, özellikle gelişmekte olan ülkelerdeki savunma sanayinin içinde bulunduğu durum göz önüne alındığında, buradaki kurumların gelişmek için devlet desteğine ihtiyaç duymaları söz konusudur. Eğer gerekli desteğin sağlanamaması söz konusu olursa, gelişmekte olan ülkelerin savunma sanayilerinden, gelişmiş ülkelere ait ve küresel olarak yayılmış savunma şirketlerinin tedarik ağına girmek zorunda kalan kurumlar anlaşılabilir. Bir görüşe göre bu durum yerel savunma şirketlerinin Ar-Ge faaliyetlerinin odak noktasının diğer ülkelerdeki kurumlar tarafindan yönlendirilmesine sebep olabilir, ayrıca üretim kapasitesi, üretim ve satın alma miktarları gibi kritik olabilecek verilerin de bilinmesine yol açabilir.

Küresel savunma sanayideki tedarik ağlarının oluşmasında, gelişmiş ülkelerdeki büyük ölçekli savunma şirketlerinin Ar-Ge ve üretim maliyetlerini düşürme çabasının rol oynadığı düşünülmektedir. Sınırları Avrupa ve Amerika dışına taşmakta olan bu şirketler diğer

\footnotetext{
${ }^{8}$ Nurullah Altun, "Savunma Harcamaları Düzeyinin Belirlenmesi: Teorik Bir Tartışma", Siyaset, Ekonomi ve Yönetim Araştırmaları Dergisi, 2017, Vol: 5 No:2, 273-285, s. 283.

9 Keith Hayward, "The Globalisation of Defence Industries", Survival, 2001, Vol.43 No:2, 115-132, s. 118.

${ }^{10}$ Deniz Şişman, "Küreselleşme, Kriz ve Savunma Sanayi", Marmara Üniversitesi Íktisadi ve Ídari Bilimler Dergisi, 2017, Vol: 39 No:1, 223-237, s. 233.
}

\section{1}

Güvenlik Stratejileri

Cilt: 16

Sayı: 33 
172

Güvenlik Stratejileri

Cilt: 16

Sayı: 33 gelişmekte olan ülkelerde yer alan kurumları satın alarak veya onlarla çeşitli ortaklıklar kurarak kendi ölçeklerini daha da geliştirmişler ve tüm dünya geneline dağıtım ağı kurma gayretine girmişlerdir. Büyük ölçekli savunma sanayi şirketleri sadece maliyetleri düşürmek değil, aynı zamanda diğer ülkelerdeki pazarlara nüfuz etmek açısından da bahsedilen yayılma stratejisini uygulamışlardır. ${ }^{11}$ Diğer bir görüşe göre, küresel savunma sanayinin tedarik ağları üzerinden gerçekleştirilmesi, savunma sanayilerini geliştirmeyi amaçlayan gelişmekte olan ülkeler için firsatlar da yaratabilir. Bir tedarik ağı içerisinde bulunmak, bu ülkelerdeki savunma sanayinin kendi üretimleri için tedarik seçeneklerini de arttıracaktır. Bu şekilde onların da kendi maliyetlerini düşürmeleri söz konusu olabilir. Ayrıca çok uluslu şirketler tarafından satın alınan veya onlarla birleşen şirketler için teknoloji transferi ve ek olarak küresel pazarlara nüfuz etme şansı doğabilir. Bu durumda, gelişmekte olan ülkelerin savunma sanayi kurum ve kuruluşlarının, küresel tedarik zincirlerinin bir parçası olması, onların bir araştırma, üretim ve bilgi ağına katılmış olmalarını sağlayabilir. ${ }^{12}$

Gelişmekte olan ülkelerdeki savunma sanayileri için devlet desteğine ihtiyaç duyulduğunda bu desteğin sağlanması için ülkenin eğitim ve sağlık gibi yine oldukça önemli faaliyetlerine daha az kaynak ayrılması zorunluluğu doğabilir. $\mathrm{Bu}$ durumda savunma sanayini tanımlarken sadece içindeki kurumlar ve onların faaliyetleri odaklı değil, genel anlamda ülkemiz ve diğer gelişmekte olan ülkelerdeki savunma sanayinin içinde bulunduğu tüm ekosistemi de göz önüne almak gerekliliği doğmaktadır. Savunma sanayi içindeki kurumların değerlendirmeleri yapılırken içinde bulundukları koşulları da incelemek daha açıklayıcı olacaktır.

${ }^{11}$ Çağlar Kurç and Stephanie G. Neuman, "Defence industries in the 21st century: a comparative analysis", Defence Studies, 2017, Vol: 17 No:3, 219-227, s. 219.

${ }^{12}$ Richard A. Bitzinger, "Chapter 3: Towards a Brave New Arms Industry?", The Adelphi Papers, 2003, 43:356, 63-79. 
Savunma Sanayinin Gelişiminin

İhracat-İthalat Dengesi Üzerindeki Etkileri

\section{Savunma Sanayindeki Ekonomik Gelişim Göstergeleri}

Bir ülkenin savunma sanayisinin gidişatını değerlendirme konusunda, literatürde farklı kaynaklarda farklı kriterlere rastlanmaktadır. Genel anlamda savunma sanayindeki gelişmeleri ele alırken savunma harcamaları, teknoloji geliştirme ve istihdam gibi farklı değerlendirmeler söz konusudur. Araştırma odaklı eserlerde sayısal veriler olarak savunma harcamaları ön planda iken sektör raporlarında teknoloji geliştirme, istihdam, yurt dışı satış gelirleri gibi pek çok farklı kritere rastlanmaktadır. Savunma sanayindeki gelişmelerin göstergesi olarak ele alınan hususlardan biri, savunma sanayindeki kurum ve kuruluşlar tarafından geliştirilen patent sayısıdır. Bu kriterin kendisi de ayrica savunma sanayi tarafindan yapılan Ar-Ge harcamaları ile ilişkilendirilmektedir. ${ }^{13} \mathrm{Bu}$ yaklaşımın temelinde yatan etmenlerden en önemlisi, savunma sanayinin gelişimi için ekonomik katkıların ancak bilimsel gelişmeler sayesinde elde edilebileceği varsayımıdır.

Savunma harcamalarının savunma sanayinin gelişimine etkisine baktı̆̆ımızda, savunma sanayideki üretim gücünün, akademi ve bilim dünyasındaki bilgi birikiminin ve orduda yer alan kaynakların, yenilikçi ürün ve sistemler yaratmak için kullanılabilmesinin savunma sanayindeki gelişmeleri ortaklaşa bir biçimde oluşturabileceği gözlemlenmektedir. ${ }^{14}$ Dolayısı ile savunma sanayindeki gelişmelerin, bir ülkenin mevcut savunma sanayinde bulunan üretim gücünün, akademik ve bilimsel seviyesinin ve ordusunun sahip olduğu kaynakların bir fonksiyonu olabileceği düşünülebilir. Bu da gelişmiş ülkelerin savunma sanayilerinin gelişmekte olan ülkelere kıyasla daha da hızlı bir şekilde gelişebileceğine işaret eder. Özellikle silah ve diğer ileri teknoloji odaklı sistem ve askerî ürünlerde gelişmiş ülkelerin daha yönlendirici olması söz konusudur. ${ }^{15}$ Savunma sanayindeki gelişmelerin ülkelerin ekonomik gelişmesi için önemli artçı etkileri de bulunmaktadır. Örneğin II. Dünya

\footnotetext{
${ }^{13}$ Özgür Uysal ve Recep Kök, a.g.y., s. 22.

${ }^{14}$ Özgür Uysal ve Recep Kök, a.g.y., s. 21.

${ }^{15}$ Deniz Şişman, a.g.y., s. 227.
}

Güvenlik Stratejileri Cilt: 16

Say1: 33 
174

Güvenlik Stratejileri

Cilt: 16

Sayı: 33

Savaşı boyunca çok çeşitli Ar-Ge faaliyetleri, devletlerin savunma sanayileri, bilim odaklı insan kaynağı ve ordularının iş birliği ile yürütülmüş ve oldukça geniş bir yelpazede, büyük buluşlara imza atılmıştır. ${ }^{16}$ İcat edilen silah teknolojilerinden farklı olarak, belirli bir amaca yönelik olarak kaynak tahsisi ve kullanımında minimizasyon sağlanmasına yol açan optimizasyon modellerinin de icadı bu dönemde gerçekleşmiştir. Bu gelişmelerin etkisi olarak, savaş bittikten sonra tüm bu yenilikler için yeni kullanım sahaları aranmış; silah ve savunma teknolojileri için ihracat yoluyla gelir elde edilmesi söz konusu olmuş; bunun dışında da, özellikle matematiksel tekniklerin ve sistematik düşünce stillerinin iş dünyasında da kullanım alanları olduğu fark edilmiştir. $\mathrm{Bu}$ dönemden sonra ihracat yoluyla savunma sanayi ürünlerinin ve teknolojilerinin diğer ülkelere ihraç edilmesi yeni pazarların oluşumuna yol açmıştır.

Savunma harcamaları ve savunma sanayinin gelişimine baktığımızda savunma harcamalarının askerî bir tehdide cevap vermek için yapıldığında yenilikçiliği daha kuvvetli bir şekilde teşvik ettiği ve dolayısı ile ekonomik büyümeyi sağlamaya daha yatkın olduğu, ancak herhangi bir güvenlik problemi veya tehdidi olmadığında yapılan savunma sanayi harcamalarının ise büyümeyi sağlamaya yönelik olmayabileceği, literatürde ortaya konulmuştur. ${ }^{17} \mathrm{Bu}$ açıdan bakıldığında askerî tehditlerin yokluğunda yapılacak savunma harcamalarının belirlenmesi için daha planlı yaklaşılması gerektiği görülmektedir. Savunma sanayinde, askerî tehditler yokluğunda, gelişmeleri ivmelendirmeyebilecek; ancak aynı zamanda caydırıcı seviyede olacak belli başlı savunma kriterlerini sağlamak için gerekli harcamaların yapılması durumu var olup, bu harcamaların düzeylerinin belirlenmesi savunma sanayindeki üretim kapasitesinin tehditler yokluğunda

${ }^{16}$ Paul Trott, Innovation Management and New Product Development, 3. Bask1, Prentice Hall, New York, s. 127.

${ }^{17}$ Joshua Aizenman ve Reuven Glick, "Military Expenditure, Threats, and Growth", Journal of International Trade \& Economic Development, 2006, Vol: 15 No:2, 129-155. s. 130. 
atıl kalmamasını sağlayacaktır. Direkt olarak Ar-Ge faaliyetlerine yol 175 açmayabilir olmakla beraber istihdam edilen personelin ve mevcut kapasitenin atıl kalmaması belirli düzeyde Ar-Ge ve teknoloji geliştirme faaliyetlerinin yürütülmesini sağlayabilir.

Savunma sanayinin gelişimi ile ilgili sektör raporlarına bakıldığında ise Ar-Ge faaliyetleri ve savunma harcamalarından daha farklı dinamiklerin bu kavramı ifade etmek için kullanıldığı görülmektedir. Özellikle gelişmiş ve savunma ve havacılık sanayileri ile dünya çapında lider konumunda olan firmalara sahip ülkelerin, savunma harcamalarında azalmalar meydana gelmesi ile savunma sanayinde, iç pazara olan satışların eksilmesi suretiyle oluşan atıl kapasiteyi kullanıma sokmak ve üzerinden gelir elde etmek için ihracata yönelmiş oldukları gözlenmektedir. ${ }^{18}$ İhracat anlamında hedefledikleri pazarlar, gelişmekte olan ülkeler (Ortadoğu, Afrika, vb.) olup ihracatı kolaylaştırıcı birtakım stratejiler izlemektedirler. Bunlardan biri, belirli seviyede teknoloji transferi ile iş ortaklıkları kurarak bir tedarik ağı oluşturmak olup, bu tür bir açılımın da savunma sanayi için bir gelişme yaratacağı söylenebilir. Bu tür ihracat faaliyetlerine girişilebilmesi için, gelişmekte olan ülkelerin finansal güç durumlarına uygun, kredilendirme ve devlet garantisi gibi konularda çeşitli mevzuatlar geliştirilmesi gerekmektedir. Dolayısı ile savunma sanayindeki gelişmelerin $\mathrm{Ar}-\mathrm{Ge}$ ve teknoloji geliştirme haricinde diğer pazarlara açılım ve küresel bir tedarik ağı kurma odaklı da olabileceği düşünülmelidir. Tüm bu farklı türdeki gelişmelerin de gerekli mevzuat ve finansal açıdan planlanması gerekmektedir. Gelişmekte olan ülkelere yapılacak ihracat faaliyetlerinin de çeşitli finansal krediler ve diğer hususlardan dolayı belirli bir maliyeti olacaktır. Bundan dolayı savunma sanayindeki Ar-Ge ve teknoloji geliştirme harici gelişmelerin de dolaylı da olsa harcamalara yol açabileceği düşünülebilir. Literatürün de ortaya koyduğu gibi savunma sanayindeki gelişmelerin ve bu gelişmeler için yapılan

\footnotetext{
${ }^{18}$ Savunma Sanayi ve İmalatçılar Derneği Resmi İnternet Sayfası, "Savunma Sanayi İhracat Kanunu Çalışmaları", http://www.sasad.org.tr/uploaded/Savunma-SanayiiIhracat-Kanunu-Calismalari.pdf (Erişim Tarihi: 14.09.2018), s. 3
}

Güvenlik Stratejileri

Cilt: 16

Say1: 33 
176

Güvenlik Stratejileri

Cilt: 16

Sayı: 33

harcamaların ülkelere ekonomik anlamda etkileri olacaktır. $\mathrm{Bu}$ etkilerden en önemli olabilecek biri de savunma harcamalarının cari açık ve ekonomik büyümeye olan etkileridir. Bu konuda iki temel görüş ortaya atılmış; ancak yapılan araştırmalar iki görüşün de geçerli olabileceği durumların varlığını ortaya koymuştur. Sonraki bölümde bu konudaki görüş ve çalışmalar incelenecektir.

\section{Savunma Harcamalarının Cari Açık ve Ekonomik Büyümeye Etkileri}

Ülkemizde savunma sanayinin kuruluş zamanlarında devletin kontrolü ve müdahalesi, sağlam bir temelin atılması için devlet otoriteleri tarafindan gerekli görülmekteydi. Benzer şekilde, ülkemizin kuruluş yıllarında diğer az gelişmiş veya gelişmekte olan devletlerde olduğu gibi stratejik sektörlere yatırım yapılması ihtiyac1 söz konusuydu ve mevcut sektör kurum ve kuruluşlarının bu yatırımları yapabilecek gücü bulunmamaktaydı. $\mathrm{Bu}$ sebeplerden dolayı devletin müdahalesini gerektiren en önemli sektörlerden biri de savunma sanayi olup devlet odaklı ve devlet yatırımlarına büyük ölçüde dayanan kurumlar savunma sanayimizin temelini oluşturmuştur. Ancak yukarıda da belirtildiği gibi, daha sonra özel kurum ve kuruluşların da savunma sanayimiz içerisinde yer alması için gerekli mevzuat düzenlemeleri yapılmıştır. Savunma sanayi odaklı veya diğer kamu iktisadi teşebbüslerine bakıldığında mevcut ekonomi kolunda lokomotif görevi görmek ve özel sektörün gelişimi için yol açmak başlıca amaçlar arasında yer almaktadır.

Devlet eliyle kurulan ve stratejik öneme sahip savunma sanayi gibi sektörlerde yer alan kamu iktisadi teşebbüsü veya devlet tabanlı diğer kurumların başarılı olması söz konusu olmazsa, ekonomik büyümeye katkıları olmayacağ 1 gibi, yaptıkları harcamalarla ekonomik açıdan zarar edilmesine de sebep olmaları mümkün olabilir. Özellikle de savunma sanayinde gelişmiş ülkelerden alınan hammadde ve benzeri malzemelerin ödemelerinin yabanc1 para birimleri ile yapıliyor olması cari açık ve ihracat-ithalat dengesine olumsuz etki yapılmasına sebep olabilir. Bu tür durumların önüne geçilebilmesi için, mümkün olduğunca, devlet tabanlı savunma sanayi kuruluşlarında yönetim kriterlerinin tarafsız olmasına, savunma teknolojilerinde küresel anlamda hizlı 
Savunma Sanayinin Gelişiminin

İhracat-İthalat Dengesi Üzerindeki Etkileri

gelişmeler yaşanabileceği için değişikliklere çabuk uyum sağlanmasına, planlama ilkelerine bağlı kalınmasına dikkat edilmelidir. ${ }^{19}$ Ülkemizde savunma sanayi sadece devlet kurumlarının tekelinde olmayıp özel sektör kuruluşları da bu çok önemli alanda faaliyet göstermektedir. Bu kuruluşlar da çeşitli fonlar ve proje destekleriyle, yine devlet tarafından desteklenmekte ve savunma sanayinde ülkemizin daha ileriye gitmesi için çaba gösterilmektedir.

Savunma sanayi odaklı faaliyetlerin en belirgin özelliği, önemli düzeyde harcamalar ile sonuçlanmalarıdır, bundan dolayı savunma harcamalarının düzeyinin tespiti önem taşıyan bir husustur ve belirli kriterlere göre düzenlenmelidir. Savunma harcamalarının belirlenmesi için savunma ihtiyacının belirlenmesi gerekir, bunun için de ülkenin içinde bulunduğu risk seviyesinin belirlenmesi gerekmektedir. ${ }^{20}$ Dolayıs1 ile adım adım izlenmesi gereken bir yol söz konusudur. Savunma ve güvenlik ihtiyacının tespiti için dış ve iç politika ile mevcut kaynakların ve teknolojik düzeyin getirdiği kısıtlamaların düşünülmesi gerekmektedir. Dış ve iç politika açısından bakıldığında ülkenin küresel anlamda erişmek istediği hedefler belirlenerek bu hedeflerin daha sonra içselleştirilmesi yapılır, savunma sanayindeki hedeflenen küresel konuma erişmek için nitelikli iş gücü istihdam hedefi belirlenmesi gibi. Sonrasında ise: yerli ve yabancı para cinsinden ekonomik kaynaklar; gerekli askerî silah, teçhizat, malzeme ve diğer sistemlerin temin edilebilmesi için zaman kısıtları; ayrıca ülkenin savunma sanayinin mevcut teknolojik düzeyinin de ihracat ve ithalat dengesinin savunma harcamalarından ne derece etkileneceği tespit edilmeye çalışılarak savunma harcamalarının düzeyi belirlenebilir. ${ }^{21}$ $\mathrm{Bu}$ çalışma, son yazılan husus üzerine değerlendirmeler esaslıdır.

19 Resül Yazıcı, “Türkiye'deki KITT'lerin Özelleştirme Tecrübelerinden Varlık Fonu Kurulmasına Bakış", Journal of Strategic Research in Social Science, 2017, Vol: 3 No:3, 89-100. s. 93.

${ }^{20}$ Maliye Bakanlığı Bütçe Mali Kontrol Genel Müdürlüğü, Savunma ve Güvenlik Hizmetleri (1924-1993), Eylül, Ankara, 1993, s. 12.

${ }^{21}$ Nurullah Altun, "Savunma Harcamaları Düzeyinin Belirlenmesi: Teorik Bir Tartışma", Siyaset, Ekonomi ve Yönetim Araştırmaları Dergisi, 2017, Vol: 5 No: 2, 273-285. ss. 274-276. 
$\mathrm{Bu}$ adımlar takip edildikten sonra ise Planlama-Programlama-Bütçeleme esaslı bir sistematik ile savunma odaklı strateji ve hedefler somut temin ve tahsis programlarına dönüştürülür; sonrasında ise bütçelenir. ${ }^{22}$

Eğer doğru düzeyde tespit edilir ve doğru alanlara yönlendirilirse savunma sanayi için yapılan harcamaların, teknolojik gelişme ve ArGe faaliyetleri için itici güç olduğu, bu durumda da diğer sanayi kollarına da etki edebilecek ve farkl1 ekonomik performans göstergelerine aynı anda pozitif etki yapabilecek bir faktör haline gelmesi gerçekleşebilir. Savunma sanayi tarafından alınan patentli buluşların pek çoğunun daha sonraları farklı sektör ve alanlarda kullanımları olabileceği ortaya çıkmış ve bu buluşların ülke ekonomisine önemli katkılarının olabileceği gözlenmiştir. Bazı açılardan bu görüşe karşı çıkanlar da bulunmaktadır, savunma harcamalarının toplumun eğitim ve sağlık gibi diğer önemli gereksinimlerine yapılabilecek harcamalar için firsat maliyeti ortaya çıkarabileceği ve dolayısı ile genel anlamda gelişmeye olumsuz etki edebileceği de ortaya atılmıştır. Ancak savunma harcamalarının ekonomik açıdan kalkınmayı sağlayabileceğini ortaya koyan araştırmalar bulunmaktadır ve bu araştırmaların da örnek olarak gösterdikleri gelişmiş ülkelerden biri, Amerika Birleşik Devletleri' dir. ${ }^{23}$

Savunma sanayi için yapılan harcamaların ekonomiye olan etkilerine odaklanıldığında iki farklı yaklaşım ve genel görüş türü öne çıkmaktadır; bu görüşler kısaca arz ve talep bakış açısı ile görüşler olarak adlandırılmaktadır. Savunma harcamalarının pek çok ülke için en önemli ve devlet bütçesinden en çok paya sahip olabilecek bir harcama türü olduğu genel olarak gözlenmektedir. ${ }^{24}$ Eğitim ve sağlık harcamalarına kıyasla, savunma harcamalarının daha fazla pay alması da yukarıda belirtilen görüşlerden birinin dikkat çektiği başlıca hususlardan biri durumundadır. Savunma harcamalarının ekonomik büyüme

${ }^{22}$ Kenan Bulutoğlu, Kamu Ekonomisine Giriş, Filiz Kitabevi, İstanbul, 1988, s. 73

${ }^{23}$ Özgür Uysal ve Recep Kök, a.g.y., s. 20.

${ }^{24}$ Peter Saunders, "Recent Trends in the Size and Growth of Government in OECD Countries", Social Policy Research Centre, UNSW, 1992, ss. 17-33. 
üzerindeki etkilerine arz odaklı bakış açısı ile yaklaşıldığında ise, savunma harcamalarının yaratacağı talebin, arzı arttırması ve yatırımları çoğaltması mümkün olduğu için ekonomik büyüme için pozitif bir etkisinin olabileceği görüşü ortaya çıkar; bu görüşe aynı zamanda Askerî Keynesçi yaklaşım da denmektedir. Diğer yandan savunma harcamalarının ekonomik büyüme üzerindeki etkilerini talep odaklı olarak ele alan Neo-Klasik Teorik yaklaşımda ise savunma harcamalarının yol açtığı maliyet, devlet bütçesinden eğitim, sağlık ve diğer sanayi kolları için ayrılabilecek payı azaltmakta ve devlet kaynaklarının direkt olarak beşeri unsurlar için ayrılmasına ket vurmaktadır. Bu bakış açısına göre savunma harcamalarının, özellikle ithalat odaklı olanların diğer sanayi kollarına yatırımları kısıtlaması ülkenin ihracat-ithalat dengesini ithalat yönünde bozucu etki yaratmakta ve dolayisı ile ekonomik büyümeye zarar verebilmektedir. ${ }^{25}$

Savunma harcamaları için talep odaklı yaklaşıma bakıldığında, gelişmekte olan ülkelerde, savunma teknolojilerinin düzeyinin gelişmiş ülkeler seviyesinde olmamasının olumsuz etkileri bulunmaktadır. Savunma faaliyetinin caydırıcılığının veya savaş zamanı koruma etkisinin olabilmesi için orduya gereken silah, sistem ve teçhizatın diğer ülkelerle aynı düzeyde olması gerektiğinden dolayı savunma sanayileri ithal girdiler ile üretim yapabilmekte ve bu durumda cari işlemlerin dengesi olumsuz yönde bozulabilmektedir. Bir ülkenin makro-ekonomik anlamda en önemli performans kriterlerinden olan cari işlemler sadece ekonomik büyümeye değil, diğer pek çok kalkınma odaklı faaliyete de direkt olarak etki etmektedir. ${ }^{26}$

Savunma harcamalarının cari açık üzerindeki etkileri iki açıdan gerçekleşebilir, bunlardan birincisi savunma harcamalarının devlet bütçesinde baskı yaratması ve borçlanma etkisine yol açma durumudur. Bir diğeri ise savunma harcamalarının ithalat odaklı olması durumunda

${ }^{25}$ Filiz Giray, "Savunma Harcamalari ve Ekonomik Büyüme”, Cumhuriyet Üniversitesi İktisadi ve İdari Bilimler Dergisi, 2004, Vol: 5 No: 1, 181-199. ss. 189-190.

${ }^{26}$ Seyfettin Erdoğan ve Hilal Bozkurt, "Türkiye'de Cari Açı̆̆ın Belirleyicileri: MGARCH Modelleri ile Bir İnceleme”, Maliye Finans Yazllarl, 2009, Vol: 23, 135-172, s. 137. 
finansman anlamında ülke dışı kaynaklara da başvurma gereksiniminin ortaya çıkabilecek olmasıdır. ${ }^{27}$ Ülkemiz de gelişmekte olan bir ülke olduğu için savunma harcamalarının cari açığa etkisi odaklı araştırmalar önem taşımaktadır. 1979-2000 yılları arası döneme bakıldığ 1 zaman kısa vadede cari açık ve askerî ihtiyaçlar için yapılan ithalat arasında olumlu ilişki gözlemlenirken, savunma harcamaları ve cari açık arasında uzun dönemde olumsuz bir bağlantı ortaya konmuştur. ${ }^{28}$ 1986-2016 aras1 döneme baktığımızda ise savunma harcamalarının cari açı üzerindeki etkisi hem kısa, hem de uzun dönemde olumsuz olarak ortaya çıkmıştır. ${ }^{29}$ İki zaman dilimi arasında ülkemizde olan değişimlere bakıldığında ise ülkemiz için savunma sanayini dışa bağımlılıktan kurtarma ve teknoloji odaklı gelişmeler sağlama politikasının özellikle ikinci zaman diliminde önemli bir etkisinin olduğu görülmektedir. Dolayısı ile savunma sanayinin teknoloji odaklı gelişimi için yatırımlar yapılmaya devam edilmesi ve devlet teşviklerinin arttırılmasının ekonomiye ve ülkemizin makroekonomik anlamda performansına çok olumlu etkileri bulunmaktadır. Savunma sanayinin gelişiminin cari açık ve genel anlamda ekonomik gelişmeye olan pozitif etkisi dâhilinde, bir sonraki bölümde sektör raporlarına dayanarak savunma sanayinin gelişimi, yurt dışı satış gelirlerinin arttırılması ve ayrıca ihracat-ithalat dengesinin olumlu yönde nasıl geliştirilebileceğine dair önerilere yer verilecektir.

\section{Savunma Sanayinin Ekonomik Gelişimi ve Yurt Dışı Satış Gelirleri ile İhracat-İthalat Dengesi Üzerindeki Etkileri}

Ülkemizin son 10-15 yıl içerisindeki savunma sanayi yatırımları ve Ar-Ge faaliyetlerine önem verme politikası sayesinde 2015 yıl1 itibariyle ulusal savunma sanayimiz ordumuzun personel, altyapı ve

${ }^{27}$ Erdal Karagöl, "Defence expenditures and external debt in Turkey", Defence and Peace Economics, 2005, Vol: 16, 117-125, s. 117.

${ }^{28}$ Selami Sezgin, "An empirical note on external debt and defence expenditures in Turkey." Defence and Peace Economics, 2004, Vol: 15 No: 2, ss. 199-203.

${ }^{29}$ Șerif Canbay ve Derya Mercan, "Savunma Harcamalarının Ekonomik Büyüme ve Cari İşlemler Dengesine Etkisi: Türkiye Örneği”, Journal of Emerging Economies and Policy, 2017, Vol: 2 No: 2, 86-104, s. 99. 
lojistik harcamaları dışındaki ihtiyaçlarının, parasal göstergelerle \%55'ini sağlayabilecek hale gelmiştir. $\mathrm{Bu}$, önemli bir başarı arz etmektedir. $\mathrm{Bu}$ başarının bir ürünü olarak da ülkemizin savunma sanayi odaklı ürünlerinde ihracat potansiyeli oldukça artmıştır. 2015 yılı rakamlarına göre 1.65 milyar dolar ihracat potansiyeli ortaya çıkmıştır. ${ }^{30}$ Tablo 1'e bakıldığında, kat edilen yolun oldukça olumlu sonuçlar doğurduğu görülmektedir. Ürün geliştirme ve teknoloji yatırımları, istihdam ile beraber artı̧ gösterdiği zaman savunma sanayinde yerelleşme görülmekte, bu da dışa bağımlılığı azaltarak ithalat rakamlarında düşüş sağlamaktadır. Buna paralel olarak, ihracat rakamlarında artış gözlenmiştir. Dolayısıyla savunma sanayindeki yerelleșme ithalat-ihracat dengesinde ihracat yönünde olumlu gelişmeye sebep olmaktadır. Sektör geneline bakıldığında bu olumlu ivmenin devam ettirilmesi için mevcut altyapının geliștirilmeye devam edilmesi ve ayrıca ülkemizin dünyanın farklı coğrafyalarında yer alan pazarlarda konumlandırılmasının yapılabilmesi için rekabet stratejilerinin geliştirilmesi gerekliliği vurgulanmaktadır.

Tablo 1. Savunma Sanayinde Yerelleșme

ve İhracat-İthalat Rakamları

\begin{tabular}{|c|c|c|c|c|}
\hline Yıl & $\begin{array}{c}\text { İthalat } \\
\text { (Milyon \$) }\end{array}$ & $\begin{array}{c}\text { Ürün/Teknoloji } \\
\text { Geliştirme } \\
\text { (Milyon \$) }\end{array}$ & $\begin{array}{c}\text { Yurt Dışı Satış } \\
\text { Gelirleri/İhracat } \\
\text { (Milyon \$) }\end{array}$ & $\begin{array}{c}\text { İstihdam } \\
\text { (Kişi) }\end{array}$ \\
\hline 2010 & - & - & 853 & - \\
\hline 2011 & - & 672 & 1100 & - \\
\hline 2012 & 1409 & 772 & 1626 & - \\
\hline 2013 & 1327 & 927 & 1570 & - \\
\hline 2014 & 1351 & 887 & 1855 & - \\
\hline 2015 & 1067 & 904 & 1929 & 31375 \\
\hline 2016 & 1289 & 1254 & 1953 & 35502 \\
\hline 2017 & 1544 & 1237 & 1824 & 44740 \\
\hline
\end{tabular}

30 Savunma Sanayi ve İmalatçılar Derneği Resmi İnternet Sayfası, "Sektörün Sürdürülebilirliği ve Rekabetçiliğin Geliştirilmesi”, http://www.sasad.org.tr/uploaded/Sekto run-Surdurulebilirligi-ve-Rekabetciliginin-Gelistirilmesi.pdf(Erişim Tarihi: 14.09.2018). 
182

Güvenlik Stratejileri

Cilt: 16

Sayı: 33

Savunma sanayimizin daha da gelişebilmesi için, sektör tabanlı altyapı geliştirme önerilerinde, ihraç edilebilecek ürünler ortaya koyma hedefi ön planda yer almaktadır. Bunun için devlet temsilcileri, özel sektör ve tüm paydaşların bir araya gelerek öncelikli ürünler, teknoloji ve sistemlerin tespit edilmesi gerekmektedir. Gelişmeye açık alanlar olarak alt-sistem tasarımı açısından savunma sanayimizin bağlı olduğu küresel tedarik ağlarında henüz tam gelişme sağlayamadığı belirtilmiş ve mevcut kapasitenin kullanımda kalması için de iç pazardaki talebin, silahlı kuvvetler için envanter yenileme projeleri ile hem sanayimiz, hem de ordu için faydalı olacak şekilde canlı tutulması gerekliliği ortaya koyulmuştur. Dünya savunma sanayi ürünleri pazarlarında rekabetçi bir politika izleyebilmemiz içinse, özellikle gelişmekte olan veya az gelişmiş ülkelerin savunma sanayimizin ürünleri için satın alma yapabilecekleri düşünüldügünde, devlet tarafindan sağlanan satış garantisi, devlet tarafindan sağlanan krediler ve diğer satış kolaylıkları, ihracat için ek teşvikler getirilmesi gibi öneriler sunulmaktadır. ${ }^{31}$

Savunma sanayimizin mevcut ürün gamına baktığımızda ise en yüksek cironun kara ve askerî havacılık ürünleri üzerinden gerçekleştiği görülmektedir. Özellikle ordumuzun, ülkemizin içinde bulunduğu ortamda sıcak çatışma içinde bulunması ve savunma sanayimizin ürünlerinin de bizzat kullanımda olması sebebiyle kara ve askerî havacılık ürünlerimizin dünya pazarlarında kabul görüyor olması beklenen bir durumdur. Dünya pazarında en büyük satış oranlarını getiren C5ISR (Command, Control, Communications, Computers, Combat Systems, Surveillance, and Reconnaissance) bilgisayar teknolojileri odaklı ve elektronik sistemler açısından ülkemiz henüz makro-ekonomik anlamda rekabet avantajı yakalayamamıştır. Yurt dışı satış gelirlerimizin büyük bir yüzdesi Avrupa ve Orta Doğu, Asya, Afrika ve Güney Amerika coğrafyaları odaklı olup daha çok gelişmekte

${ }^{31}$ Savunma Sanayi ve İmalatçılar Derneği Resmi İnternet Sayfası, a.g.y., (Erişim Tarihi: 14.09.2018) 
olan ve az gelişmiş ülkelere ihracat yapma potansiyeli söz konusudur. ${ }^{32}$

Savunma sanayi ile ilgili Ar-Ge ve teknolojik gelişme trendi 2015 sonrası raporlarda da görülmekte olup bu noktada ülkemizin ihracat ve yurt dışı satış gelirlerinin arttırılması ile ilgili politikalar geliştirilmelidir. Dünyadaki, savunma sanayilerinin küreselleşmesi ve ülkeler arası bir tedarik ağı kurulması trendi gereği ülkemizin hak ettiği yere gelebilmesi için bu faaliyetler büyük önem taşımaktadır. İhracat odaklı tanıtım faaliyetleri olarak ülkemizin devlet ve özel sektör temsilcilerinin diğer ülke temsilcileri ile ziyaretler gerçekleştirmesi ve ayrıca uluslararası fuarlara katılım için, gerektiğinde, devletin destek sağlaması da önerilmektedir. Finansman açısından, yine, kredilendirme, teşvik ve barter türü uygulamaların gerçekleştirilmesi için gerekli mevzuat ve onayların sağlanmasının ihracat-ithalat dengesinin ihracat yönünde ilerlemesi ve yurt dışı satış gelirlerinin artışına büyük katkı sağlayacağı belirtilmektedir. ${ }^{33}$ Tüm bu yapılabilecekler arasında en önemli yer tutan husus ise, ülkemizin, savunma sanayinde Ar-Ge ve teknoloji odaklı çalışmaları arttırarak bu alanda ilerleme kaydetmeye önem vermeye devam etmesidir.

\section{Sonuç}

Bu çalışmada savunma sanayi kavramı irdelenmiş, sonrasında ise savunma sanayindeki ekonomik gelişme kavramı tanımlanmıştır. Savunma sanayi bir ülkenin ve devletinin halkına sağlaması gereken en önemli ve hayati hizmetlerden olan savunma hizmetine cevap verecek ürün, teçhizat ve sistemleri oluşturmakla görevlidir. Ancak savunma hizmeti savunma ihtiyacına cevap vermek için gerçekleştirilmekte olup barış zamanı caydırıcı olmak, savaş zamanı da koruyucu olmak

\footnotetext{
32 Savunma Sanayi ve İmalatçılar Derneği Resmi İnternet Sayfası, a.g.y., (Erişim Tarihi: 14.09.2018).

${ }^{33}$ Savunma Sanayi ve İmalatçılar Derneği Resmi İnternet Sayfası, "Savunma ve Havacıllk Sanayi Performans Raporu 2016 \& 2017", http:/www.sasad.org.tr/uploaded/SasadPerformans-Raporu-2016.pdf, http://www.sasad.org.tr/uploaded/Sasad-Performans-Raporu2017.pdf (Erişim Tarihi: 14.09.2018).
}

\section{3}

Güvenlik Stratejileri

Cilt: 16

Say1: 33 
184

Güvenlik Stratejileri

Cilt: 16

Sayı: 33 durumundadır. Dolayısı ile diğer ülkelerin savunma güçlerinin de bir ülkenin savunma ihtiyacı ve bunun için gerekli hizmetin verilmesinde önemli rol oynaması söz konusudur.

Savunma sanayindeki gelişmelerin tanımı açısından literatürde farklı göstergeler ortaya atılmakla beraber, savunma harcamalarının, sıklıkla başvurulan, savunma sanayindeki gelişimi belirleyici bir etken olduğu söylenebilir. Savunma harcamalarının, ekonomik açıdan çok önemli olan bir başka gösterge olan cari açık üzerindeki etkilerine bakıldığında ise, savunma sanayindeki gelişimi ortaya koyan savunma harcamalarının hangi ürün ve kalemler için yapıldığına göz atmak gerekmektedir. Bundan kastedilen, savunma harcamalarının ülkenin savunma sanayisinin dışa bağımlılığını azaltmak ve kendi teknolojilerini üretmek için gerekli yatırımlar amaçlı yapılan harcamalar mı yoksa ithal ürünler ile savunma ihtiyaçlarını karşılamak için yapılan harcamalardan $\mathrm{m} 1$ oluştuğunu değerlendirmektir. Bu alanda iki farklı ana görüş ortaya atılmakta olup, arz bakış açısı odaklı görüş savunma harcamalarının yarattığı yatırımların diğer sektörler üzerinde de olumlu etki yaptı̆̆ını ortaya atar. Talep odaklı görüş ise savunma harcamalarının, devlet bütçesinin daha büyük bir kısmının eğitim ve sağlık gibi beşeri unsurlara aktarılmasını engellediği için ekonomik büyümeyi olumsuz etkilediğini savunmaktadir.

Savunma harcamalarının niteliğinin ve amaçlarının ekonomik büyüme ve ayrıca bir ülkenin makroekonomik konumunu belirleyen göstergelerden olan cari açık açısından etkilerini değerlendirmek üzere yapılan araştırmalarda savunma sanayindeki teknolojik düzey arttıkça savunma harcamalarının cari açık üzerinde hem kısa, hem de uzun vadede olumsuz etkilerinin olduğu ortaya koyulmuştur. Dolayısı ile savunma sanayine yatırım yapıldıkça cari açığın azalması ve ihracatithalat dengesinin ihracat yönünde ilerlemesi mümkün olacaktır. Bir ülke için savunma sanayine yapılan yatırımlar, sadece savunma hizmetinin karşılanması için değil, aynı zamanda o ülkenin savunma sanayisinin bu alandaki küresel tedarik zincirlerinde üstün bir konumlandırma yapabilmesi için ortaya koyulmalı ve ayrıca rekabetçi pazarlama ve konumlandırma stratejileri ile desteklenmelidir. 
Savunma Sanayinin Gelişiminin

İhracat-İthalat Dengesi Üzerindeki Etkileri

\section{Summary}

Turkey has been at the centre of war zones on most of its borders, and therefore needs to constantly give emphasis and importance to the development of its defence industry. Another reason for this requirement is the continuous push on the countries to improve their defence industries due to the continuous trend of wars, which started with World War II, and then continued with the Cold War, 9/11, Afghanistan, and Iraq operations.

Turkey has given great emphasis on the development of its defence industry in its founding years, but demonstrated mixed approaches on whether to supply the defence needs from internal or external resources. Until the Cold War era, the country supplied its army's needs from internal defence industry resources; but during the Cold War era, due to the political standing on the side of United States, the country had agreements on defence supplies and satisfied the needs externally. However, time presented this approach to be unfruitful and the country went back to supporting the national defence industry until today.

In the Cold War period, external dependency was experienced, and in the later decades the internal resources-oriented defence industry development process was continued. However, defence technologies in the world are constantly evolving and it is not possible for a country to dominate all technological needs on its own. In this case, some of the defence needs should be met from national defence industry and some from external sources. The effects of these two approaches on economic growth and the current macro-economic indicators such as current account deficit will be different. The most important factor affecting these spending trends is the developments in the defence industry. As the technological level in the defence industry progresses, it is up to the country's own preference that the expenditures be external or internal. This is expected to have a positive impact on the economy. In this study, the effects of advances in defence industry on the export-import balance were examined and a synthesis was obtained by collecting the studies done at different times in the literature. 
186

Güvenlik Stratejileri

Cilt: 16

Sayı: 33

There are different concepts in the literature for the definition of economic development in the defence industry; the most common of these are the patents expressing the technological progress and the defence expenditures that provide them. There is considerable research looking at the impact of defence spending on economic growth and other economic indicators. These studies were conducted based on data covering different time periods and presented different results. Recent research has shown that defence expenditures have a positive effect on exports and imports in both short and long term. However, in the previous academic studies, this positive result is not fully realized. When this observation is imposed on the industry reports, it has been revealed that our country has given importance to the development of the defence industry in the recent past and thus the technological level of our defence industry has increased.

According to the results of these findings, investments for the technology-oriented development of the defence industry and the increase of government incentives have very positive effects on the economy and the macro-economic performance of our country. Therefore, it will be possible to decrease the current account deficit and to move forward the export-import balance in the direction of export. Investments in the defence industry for a country should be put in place not only to meet defence services, but also to ensure that the defence industry of that country has a superior position in the global supply chains in this area and should also be supported by competitive marketing and positioning strategies. 
Savunma Sanayinin Gelişiminin

İhracat-İthalat Dengesi Üzerindeki Etkileri

Kaynakça

Kitaplar

ASLAN, M. Hanifi, Hizmet Ekonomisi, Alfa Yayınevi, İstanbul, 1998.

BITZINGER, Richard A., "Chapter 3: Towards a Brave New Arms Industry?", The Adelphi Papers, 2003, 43:356, 63-79.

BULUTOĞLU, Kenan, Kamu Ekonomisine Giriş, Filiz Kitabevi, İstanbul, 1988.

BULUTOĞLU, Kenan, Kamu Ekonomisine Giriş, Demokraside Devletin Ekonomik Kuramı, Yap1 Kredi Yayınları, İstanbul, 2003.

Maliye Bakanlığı Bütçe Mali Kontrol Genel Müdürlügü, Savunma ve Güvenlik Hizmetleri (1924-1993), Eylül, Ankara, 1993.

SAUNDERS, Peter, "Recent Trends in the Size and Growth of Government in OECD Countries", Social Policy Research Centre, UNSW, 1992.

TROTT, Paul, Innovation Management and New Product Development, 3. Bask1, Prentice Hall, New York, 2012.

\section{Makaleler}

AIZENMAN, Joshua ve Reuven GLICK, "Military Expenditure, Threats, and Growth", Journal of International Trade \& Economic Development, 2006, Vol: 15 No:2, 129-155.

ALTUN, Nurullah, "Savunma Harcamaları Düzeyinin Belirlenmesi: Teorik Bir Tartışma", Siyaset, Ekonomi ve Yönetim Araştırmaları Dergisi, 2017, Vol: 5 No:2, 273-285.

CANBAY, Şerif ve Derya MERCAN, "Savunma Harcamalarının Ekonomik Büyüme ve Cari İşlemler Dengesine Etkisi: Türkiye Örneği”, Journal of Emerging Economies and Policy, 2017, Vol: 2 No:2, 86-104.

ERDOĞAN, Seyfettin ve Hilal BOZKURT, "Türkiye'de Cari Açığın Belirleyicileri: MGARCH Modelleri ile Bir İnceleme”, Maliye Finans Yazıları, 2009, Vol: 23, 135172.

GIRAY, Filiz, "Savunma Harcamalari ve Ekonomik Büyüme", Cumhuriyet Üniversitesi İktisadi ve İdari Bilimler Dergisi, 2004, Vol: 5 No: 1, 181-199.

HAYWARD, Keith, "The Globalisation of Defence Industries", Survival, 2001, Vol.43 No:2, 115-132.

KARAGÖL, Erdal, "Defence expenditures and external debt in Turkey", Defence and Peace Economics, 2005, Vol: 16, 117-125.

KURÇ, Çağlar and Stephanie G. Neuman, "Defence industries in the 21st century: a comparative analysis", Defence Studies, 2017, Vol: 17 No:3, 219-227.

SEZGIN, Selami, "An empirical note on external debt and defence expenditures in Turkey." Defence and Peace Economics, 2004, Vol: 15 No: 2, 199-203.

ŞiŞMAN, Deniz, "Küreselleşme, Kriz ve Savunma Sanayi", Marmara Üniversitesi İktisadi ve İdari Bilimler Dergisi, 2017, Vol: 39 No:1, 223-237.

THOMPSON, Earl A., "Taxation and National Defense", The Journal of Political Economy, 1974, Vol: 82 No:4, 755-782. 


\section{Orkun BAYRAM}

188

Güvenlik

Stratejileri

Cilt: 16

Sayı: 33

UYSAL, Özgür ve Recep KÖK, “Ordu Ar-Ge Harcamalarının Ordunun Milli Gelirden Aldığı Paya Oranının Savunma Sanayi Patentlerine Etkileri”, Sanayii Şurasl, 2013, Vol: 3, 20-33. http://www.sanayisurasi.gov.tr/pdfs/ordu-ar-ge-harcamalarininordunun-milli-gelirden-aldigi-paya-oraninin-savunma-sanayi-patentlerine-etkileri.pdf, (Erişim Tarihi: 10.09.2018)

YAZICI, Resül, "Türkiye'deki KIT'lerin Özelleştirme Tecrübelerinden Varlık Fonu Kurulmasına Bakış", Journal of Strategic Research in Social Science, 2017, Vol: 3 No:3, 89-100.

\section{Internet Siteleri}

Savunma Sanayi ve İmalatçılar Derneği Resmi İnternet Sayfası, "Savunma Sanayi İhracat Kanunu Çalışmaları", http://www.sasad.org.tr/uploaded/Savunma-SanayiiIhracat-Kanunu-Calismalari.pdf (Erişim Tarihi: 14.09.2018)

Savunma Sanayi ve İmalatçılar Derneği Resmi İnternet Sayfası, "Savunma ve Havacilik Sanayi Performans Raporu 2016 \& 2017”, http://www.sasad.org.tr/uploaded/Sasad-Performans-Raporu-2016.pdf, http://www.sasad.org.tr/uploaded/Sasad-Performans-Raporu-2017.pdf (Erişim Tarihi: 14.09.2018)

Savunma Sanayi ve İmalatçılar Derneği Resmi İnternet Sayfas1, "Sektörün Sürdürülebilirliği ve Rekabetçiliğin Geliştirilmesi", http://www.sasad.org.tr/uploaded/Sektorun-Surdurulebilirligi-ve-RekabetciligininGelistirilmesi.pdf (Erişim Tarihi: 10.09.2018) 